\title{
Adoption of Yam minisett technology by farmers \\ EVALUATION OF FACTORS DRIVING THE ADOPTION OF YAM MINISETT TECHNOLOGY BY FARMERS IN ABIA STATE, NIGERIA.
}

\author{
**H.N. ANYAEGBUNAM, ${ }^{1}$ C. I. EZE * M.C OGBONNA AND *D. S. KORIEOCHA \\ **Extension Services Programme, National Root Crops Research Institute, Umudike P.M.B 7006 Abia \\ State. (+2348034684975) E-mail (helenkol8@yahoo.com.) \\ ${ }^{1}$ Department of Agric. Economics, Abia State University, Uturu. Abia State
}

\begin{abstract}
The study was carried out to evaluate the socio-economic factors influencing adoption of yam minisett technology by farmers in Abia State. 120 farmers were purposively selected from the three agricultural zones of the state namely Aba, Ohafia and Umuahia respectively. Primary data for the study were collected on respondents' socioeconomic characteristics, use of minisett technology and constraints militating the adoption of yam minisett technology using structured questionnaire. Data were analyzed using descriptive statistics such as frequency count and percentages. Ordinary least square regression analysis of the double log form was used to determine the socioeconomic factors influencing adoption of yam minisett technology by the respondent farmers. Results showed that farmers fall within the age brackets of 40-50 years. Farm size $(t=2.99)$, Educational level $(t=2.75)$ and credit availability $(t=3.03)$ are positive and significant. $(P=0.05)$ The problems farmers encountered included high cost inputs, and unavailability of credit facility. Others are procurement of land and insufficient extension services in that order. Conclusion is drawn that farm size, educational level and credit availability are the socio-economic factors influencing the adoption of yam minisett technology. It is then recommended that Government should evolve positive policies which will ensure that soft loans are given to genuine farmers at minimal interest rate and the farmers should be monitored to properly use the loan. This will enable them increase their farm size, procure inputs, adopt innovations and consequently improve agricultural production.
\end{abstract}

KEYWORDS: Socio-economic, Adoption, Yam Minisett,

\section{INTRODUCTION}

Yam (Dioscorea spp) is an important tuber crop in Nigeria, where it is produced mainly as a source of food crop especially carbohydrate. The current annual production is estimated at 26.587 million metric tons (FAO, 2005). In 1997 alone, Nigeria accounted for $75 \%$ of the world production (Manyong et al, 2001. Although yam production in Nigeria is quite high there is still need for increased production to satisfy domestic and possibly export demand (Asumugha et al, 2004).

However, production of yam is highly expensive when compared with other root and tuber crops. This is due to costly input requirements, especially labor and planting materials (Ezeh, 1998). For both seed yam and ware yam production, planting materials may exceed 50\% of production cost (Orkwor 1998.) A large quantity of edible yam up to $30 \%$ of the previous year's harvest may be used to plant a new crop (Okoli and Akoroda, 1995). This makes seed yams account for the high cost of total production cost.

The minisett technique involves the use of $25 \mathrm{~g}$ of setts to produce whole tubers which serve as "seed" yam (Okoli and Akoroda, 1995). This technology was developed to address the problem of high cost of seed yam. Yam minisett technology is a package comprising of the following field operations (i)Land preparation (ii)use of minisett dust( iii) time of planting-when rains become stable( iv)sett size of $25 \mathrm{~g}$ (v)seed bed preparation( vi)spacing of $25 \mathrm{~cm} \times 1.0 \mathrm{~m}$ (vii)use of fertilizer(Iwueke,1991). The rate of adoption of the minsett technique was low(,Iwueke, 1991)The adoption rate was reported as low as $40 \%$ (Chikwendu et al.1994,Ogbodu,1995Anuebunwa et al 1998) This was partly because seed yams vary with ecological zones and farming systems in Nigeria(Asumugha and Eluagu,1999).The study therefore addresses the following 
objectives;

i. Describe the socioeconomic characteristics of the respondents in the study area;

ii. Determine the socioeconomic factors influencing adoption of yam minisett technology by farmers in the study area;

iii Identify the constraints to the adoption of yam minisett technology

iv. State the policy implications of the study.

\section{METHODOLOGY}

Abia State was purposely chosen for the study because it is one of the major food producing states in Nigeria. The data for the study were collected through structured questionnaire. A multistage random sampling technique was used to select 120 respondents from the three agricultural zones of the state namely Aba, Ohafia and Umuahia. The analysis was done using descriptive statistics such as percentages, frequency counts and the ordinary least square regression model The model is expressed implicitly as follows:-

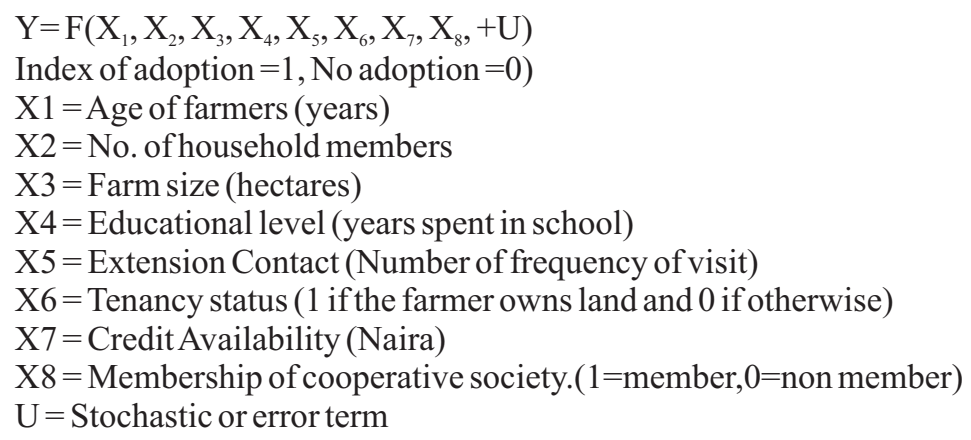

The regression analysis was expressed in three functional forms namely Linear, Semi-log and double log. The lead equation (double log) was chosen based on the performance of $\mathrm{R}^{2}$, F-ratio and parameter estimates.

\section{RESULTS AND DISCUSSION}

Table 1 summarizes the socioeconomic characteristics of Respondents in the study area. These include distribution according to Age of farmers, Household size, farm size, Educational level and Extension contact. Others are Tenancy status, credit availability and membership of cooperative society. The table shows that higher percentage of respondents fall within the 40-50 age brackets indicating highest adoption by middle age while youths comprised of $22.5 \%$ of the total respondents. The Household size of respondents range from 6-10 which is the highest (60.83\%) while respondents with household size of above 10 was $4.17 \%$.

Majority (41.67\%) of the farmers have farm sizes ranging from $1.5-2.0$ hectares while $35.83 \%$ of the respondents have farm sizes ranging from $0.5-1.0$ hectares. This shows that farmers from these areas are smallscale farmers (Olayide, 1980). Distribution of respondents according to educational status reveals that the $18.33 \%$ respondents had no formal education (illiterates), $29.17 \%$ had primary education, while $52.50 \%$ of the respondents completed secondary and tertiary education implying the most of the respondents are literate. Education has an important role to play in the adoption of modern technologies. According to Chinaka et al. (1995), farmers' level of education influences his level of adoption of modern technologies.). Table 1 also explains that $87.50 \%$ of the farmers were visited 1-6 times by Extension Agents during a planting season. Visit by the Extension Agents to the farmers is very important. It will enable the Extension Agent Monitor the farmers closely to ensure that monitoring and evaluation processes which precede adoption stage are achieved. The implication is that the more regular the visit, the more the farmers adopt new ideas $77.5 \%$ of the farmers inherited their farm land, $5 \%$ got theirs from communal ownership and $28.33 \%$ rented theirs. This implies that farmers in the study area invested less in the procurement of farmland. This is due to the fact that they are poor

Niger Agric. J. 40 No. 1 (2009): 169 - 174 


\section{Adoption of Yam minisett technology by farmers}

and cannot afford much in terms of finance to expand their farmland. They therefore rely on inherited parcels of land for their farming operations. About $73.33 \%$ of the respondents secured their funds from personnel savings while $26.67 \%$ borrowed money either from Isusu, money lenders or Banks to finance their farm operations. The distribution of the respondents according to membership of cooperative shows that $67.67 \%$ of the respondents never belonged to any cooperative while $33.33 \%$ belonged to one cooperative or the other.

Table 1: Summary of Socioeconomic Characteristics of Respondents in the study area

\begin{tabular}{|c|c|c|}
\hline Variables & Frequency & Percentage $(\%)$ \\
\hline \multicolumn{3}{|l|}{ Age: } \\
\hline $30-40$ & 27 & 22.50 \\
\hline $40-50$ & 48 & 40.00 \\
\hline $50-60$ & 29 & 24.17 \\
\hline Above 60 & 16 & 13.33 \\
\hline Total & 120 & 100 \\
\hline \multicolumn{3}{|l|}{ Household size: } \\
\hline $2-5$ & 42 & 35.00 \\
\hline $6-10$ & 73 & 60.83 \\
\hline Above 10 & 05 & 4.17 \\
\hline Total & 120 & 100 \\
\hline \multicolumn{3}{|l|}{ Farm size (hectare): } \\
\hline $0.5-1.0$ & 43 & 35.83 \\
\hline $1.5-2.0$ & 50 & 41.67 \\
\hline $2.5-3.0$ & 17 & 14.17 \\
\hline $3.5-4.0$ & 10 & 07.50 \\
\hline Total & 120 & 100 \\
\hline \multicolumn{3}{|l|}{ Educational Status: } \\
\hline No Formal education & 22 & 18.33 \\
\hline Primary & 35 & 29.17 \\
\hline Secondary & 40 & 33.33 \\
\hline Tertiary & 23 & 19.17 \\
\hline Total & 120 & 100 \\
\hline Extension Visits: & 105 & 87.50 \\
\hline \multicolumn{3}{|l|}{ No. of visits 1-6 } \\
\hline $7-9$ & 02 & 1.67 \\
\hline Above 9 & 06 & 5.00 \\
\hline No visit & 07 & 5.83 \\
\hline \multicolumn{3}{|l|}{ Tenancy Status } \\
\hline Inheritance & 80 & 66.67 \\
\hline Communal & 06 & 5.00 \\
\hline Rental & 34 & 28.33 \\
\hline Total & 120 & 100 \\
\hline \multicolumn{3}{|l|}{ Source of finance } \\
\hline Personal savings & 88 & 73.33 \\
\hline Borrowed & 32 & 26.67 \\
\hline Total & 120 & 100 \\
\hline \multicolumn{3}{|c|}{ Membership of cooperative } \\
\hline Members & 40 & 33.33 \\
\hline Non members & 80 & 66.67 \\
\hline Total & 120 & 100 \\
\hline
\end{tabular}

Source: Field Survey data, 2006 
Table 2 highlights the results of the Regression Analysis using the Double Log. For a cross sectional analysis, the results indicate that the equation provided reasonably good estimate of the underlying socio-economic characteristics that influence the adoption of yam minisett technology $(\mathrm{R}=0.515)$

Examining the individual characteristic reveal that age of the farmers is not statistically significant at 5 percent level of probability. Though age of the farmers coefficient (3.7) is positive, it is not significant. It thus appears that age of the farmers is not an important determinant in adoption of yam minisett technology.

The regression result shows that household size is negative but strong. The household size coefficient is ($80.99)$ and statistically significant $(\mathrm{P} \leq 0.5)$. This did not agree with earlier work on adoption studies (Chinaka et al.1995and Imo, 2005) Labour as one of the factors of production tends to increase adoption when appropriately combined with other limiting factors of production. This is due to the fact that the required labour is supplied by the farmer's children and close relations. Hence this parameter is a strong determinant of adoption of yam minisett technology.

The relationship between farm size and adoption of yam minisett technology is strong and positive. It is statistically significant $(\mathrm{P}<0.05)$. Its coefficient is 38.56 . The $\mathrm{t}$ (calculated) $=2.99$ is greater than the $\mathrm{t}$ (tabulated) of 1.98. The implication is that farm size influences adoption of yam mini sett technology. This result agreed with a priori expectation that total farm size of farmers may influence adoption of new technology as owners of large farm usually have more resources than small-scale farmers,(Imo,2005);

Educational level is positive and strong. The coefficient (47.82) is significant $(\mathrm{P} \leq 0.05)$. This result indicates that educational status is a strong determinant of adoption of yam minisett technology. It implies that education removes conservative attitude of the farmers and increases the risk taking abilities of the farmers. Also it explained that the more educated a farmer is, the more receptive he is to accept new ideas. (CIMMYT, 1993; Chinaka et.al 1995) The number of extension contacts $\left(\mathrm{x}_{5}\right)$ did not have a significant effect on the adoption of yam minisett technology at the 5 percent level. The coefficient $(+11.25)$ is relatively strong and positive. This suggests that the extension agents were very ineffective in the discharge of their duties. This may be due to the conflicting demands on their times and job as they are required to service a great number of farmers over a large geographical area.

The relationship between tenancy status of farmer and the adoption of yam minisett technology is negative. The co-efficient (-18.20) measuring the dummy variable is not statistically significant at 5 percent level of probability. Hence tenancy status is not a determinant of adoption level of yam minisett technology.

The results of the analysis also reveal that those farmers with access to credit are better adopters than those without access. The coefficient (3.03) is strong and positive. It is significant at the 5 percent level. There is the existence of economics of scale in farming business this in agreement with earlier work on credit availability and adoption (Anyaegbunam et al .2006). The result of membership of co-operative society and the adoption level of yam minisett technology is weak and positive. The coefficient (0.38) is not statistically significant at the 5 percent level. Some explanations could be adduced for this weak relationship. The co-operatives in the area under study has been locked in series of leadership squabbles. This problem have resulted in the members not delivering the full benefits of co-operative because of lack of meetings and divided loyalty to different interest groups 
Adoption of Yam minisett technology by farmers

Table 2: Summary of Regression Analysis (Double Log) on determinant of Adoption of yam minisett Technology

\begin{tabular}{lc}
\hline Determinant Variables & Coefficients \\
\hline Constant & $73.47(2.52)^{* *}$ \\
$\mathrm{X}_{1}$ Age of farmers & $3.7(0.16)$ \\
$\mathrm{X}_{2}$ Number of household & $-80.99(-2.41)^{* *}$ \\
$\mathrm{X}_{3}$ Farm size (Hectares) & $38.56(2.99)^{* *}$ \\
$\mathrm{X}_{4}$ Educational level(years spent in school) & $47.82(2.75)^{* *}$ \\
$\mathrm{X}_{5}$ Extension Contact (No of frequency of visit) & $11.25(0.83)$ \\
$\mathrm{X}_{6}$ Tenancy Status (1 if the farmer owns the land and 0 otherwise) & $-18.20(-1.45$ \\
$\mathrm{X}_{7}$ Credit Availability & $18.31(3.03)^{* *}$ \\
$\mathrm{X}_{8}$ Membership of cooperative society & $0.38(0.03)$ \\
$\mathrm{R}^{2}$ & 0.515 \\
\hline
\end{tabular}

Figures in parenthesis represent t-ratios, ** Significant at $5 \%$ level.

Constraints to yam minisett adoption on the study area are shown on Table 3. High cost of inputs ranked first among the constraints. These inputs include fertilizer, minisett dust and other inputs. This is closely followed by unavailability of credit, possibly because the farmers are poor and lack the necessary collaterals. There are other problems of procuring land farming and insufficient extension services in that order.

Table 3: Constraints to the adoption of adoption of yam minsett technology.

\begin{tabular}{|l|l|l|l|}
\hline Constraint & Frequency & *Percentage & Remark \\
\hline High cost of inputs & 110 & 91.67 & 1 \\
Unavailability of credit facility & 90 & 75.06 & 2 \\
Problem of procuring land & 70 & 58.33 & 3 \\
Insufficient extension services & 40 & 33.3 & 4 \\
\hline
\end{tabular}

* Multiple responses recorded. Source: Field Survey 2006.

\section{CONCLUSION}

The findings show that the educational level of the respondents, farm size and availability of credit are significant factors or determinants influencing adoption of yam minisett Technology by farmers in Abia state. The coefficients $(2.75,2.99$ and 3.03) are significantly positive $(\mathrm{P}=05)$. The findings also revealed that highest adoption was among the middle age farmers who are between $40-50$ years The major constraint militating against the adoption of the technology is high cost of inputs followed by unavailability of credit facility .Others are problem of procuring land and insufficient extension services.. It is advised that. Government should evolve positive policies which will ensure that soft loans are given to genuine farmers at minimal interest rate and the farmers should be monitored to ensure that the loan is judiciously utilized. This will enable them increase their farm size, procure inputs, adopt innovations and consequently improve agricultural production.

\section{REFERENCES}

Anuebunwa, F.O; B.O, Ugwu; D.O, Onu; A.W, Iloka, J.E.G. Ikeorgu and A. Udealor (1998) "Extent of adoption of improved yam minisett technologies by farmers in the major yam producing areas of Nigeria." Research report NRCRI, Umudike, submitted to NARP/World Bank, Abuja Nigeria. . 


\section{H.N. Anyaegbunam, C. I. Eze M.C Ogbonna and D. S. Korieocha}

Anyaegbunam, H.N; C.I Eze; G.O. Chukwu and G.N. Asumugha (2006) "Credit Availability to Farmers in Relation to Adoption of Selected Farm Technologies in Abia State, Nigeria". Journal of Sustainable Tropical Agricultural Research, vol19, Treasure Publishers Nigeria.

Asumugha G.N and L.S Eluagu(1999)" Increased adoption of modified yam minsett technology in Nigeria"; Critical issues and Information support mechanisms' paper presented at the $15^{\text {th }}$ Annual Conference of the Farm Management Association of Nigeria (FARM) held at Bayero University Kano ,Nigeria

Asumugha G.N; B.O Ugwu, O.C. Aniedu and K.Amegbeto (2004) "Minisett Technique of Seed Yam Production in Two major yam producing states of Nigeria": A function of input Availability and Production Objective. Proceeding of $9^{\text {th }}$ ISTRC-AB symposium, Kenya. Pp. 209-215

Chinaka, C.C., D.O. Chikwendu and G.N. Asumugha (1995)" A socio-economic study of the Adoption and Sustainability of improved cassava varieties among Resource Poor Farmers in South-East Zone of Nigeria "In" Root crops and Poverty Alleviation. International Society for Tropical Crops African Branch Malawi Pp. 333-336.

Chikwendu, D.O.,C.C Chinaka and A.M Omotayo (1994)"Adoption of minisett technique of seed yam production by farmers in Eastern Forest Zone of Nigeria' discovery and Innvation.7(4):367-375.

CIMMYT (1993) "The Adoption of Agricultural Technology: A Guide for survey Design. CIMMYT Economics Programme Pp. 41-46

Ezeh, N.O.A (1994) Economic of seed yam production from minisetts in Umudike in Southeastern Nigeria, Implication for Commercial growers 'In' Proceeding of the Ninth Symposium of the International Society of Tropical Root Crops Pp. 378-381

FAO (2005), Food and Agricultural Organization of the United Nations Statistics (FAOSTAT Data Base Results).FAO ROME, Italy.

Imo,A.N and M.U Essien (2005)'Adoption of Improved Cassava varieties amohg small-scale farmers' in Ikot Ekpene agricultural zone of Akwa Ibom State, Nigeria. A paper presented at the $39^{\text {th }}$ Annual conference of the Agricultural Society Of Nigeria held at the Universit of Benin,Benin City Nigeria Pp. 1-4.

Iwueke,C.C(1991) "Appraisal of yam minisett technique by farmers in southeastern states in Nigeria.":In" Olukosi,J.O;Ogungbile,A.O; and Kalu,B.A(eds) Appropriate agricultural technologies for resourcepoor farmers, Ahmadu Bello University Zaria, Nigeria. Pp. 247-254.

Manyong, V.M., R. Asudu and G.O. Olaniyan (2001) "Farmers' perception and actions on Resource Management Constraints in the yam Based Systems of western Nigeria "In" M.O. Akoroda and J.M. Ngeve, Root Crops in the $21^{\text {st }}$ century. Proceeding of the $7^{\text {th }}$ symposium ISTRC_AB, Cotonou, Benin Republic. Pp. 156-167

Ogbodu, B (1995), Report on extension activities in Enugu State, presented at the $10^{\text {th }}$ Annual zonal farming Systems Research and Extension workshop,Pp. 4-8.

Okoli, O.O. and M.O Akoroda (1995), "Providing seed tubers for the production of food of yams. African Journal of Tuber Root and Tuber Crops. Vol. 1 No 1 Pp. 1-6.

Olayide, A.A (1980)'Characteristics, problems and significance of farmers 'In' Olayide, S.O. ,J.A Eweka and V.E Osagie (eds.)Problems and prospects in Integrated Rural Development, Ibadan centre for Agricultural and Rural Development (CARD) Pp. 11-14.

Orkwor G.C and A.A. Adeniji (1998) "Production constraints and Available Technologies for food yam (Dioscorea spp) production in Nigeria "In' yam old plant and crop for future. J. Bethaud, N. Bricas, J.I Marchland eds. Montpellier, France Pp. 409-414.

Niger Agric. J. 40 No. 1 (2009): 169 - 174

$-174-$ 